Pesq. Vet. Bras. 35(Supl.1):39-50, dezembro 2015 DOI: $10.1590 / \mathrm{S} 0100-736 \mathrm{X} 2015001300008$

\title{
Histomorphometric analysis of the Achilles tendon of Wistar rats treated with laser therapy and eccentric exercise ${ }^{1}$
}

\author{
Maria V. de Souza ${ }^{2 *}$, José do C.L. Moreira ${ }^{3}$, Micheline O. da Silva ${ }^{4}$, Júlio Crepaldi' \\ Carlos Henrique Osório Silva ${ }^{6}$, Silvana L.R. Garcia ${ }^{7}$ and Antônio José Natali ${ }^{8}$
}

\begin{abstract}
Souza M.V., Moreira J.C.L., Silva M.O., Crepaldi J., Silva C.H.O., Garcia S.L.R. \& Natali A.J. 2015. Histomorphometric analysis of the Achilles tendon of Wistar rats treated with laser therapy and eccentric exercise. Pesquisa Veterinária Brasileira 35(Supl.1):3950. Departamento de Veterinária, Universidade Federal de Viçosa, Avenida Peter Henry Rolfs s/n, Campus Universitário, Viçosa, MG 36570-000, Brazil. E-mail: msouza@ufv.br

Low-level laser therapy is recommended for the treatment of tendinopathies despite the contradictory results related to the ideal dose of energy, wavelength and time of application. This study aimed to assess the effects of laser therapy and eccentric exercise on tendinopathy of the Achilles tendon of Wistar rats. Forty-eight adult male rats were randomly distributed into four groups $(\mathrm{L}=$ laser; $\mathrm{E}=$ eccentric exercise; $\mathrm{LE}=$ laser and eccentric exercise; and $\mathrm{R}=$ rest). Laser therapy $\left(904 \mathrm{~nm} / 3 \mathrm{~J} / \mathrm{cm}^{2}\right)$ and/or eccentric exercise (downhill walking; $15^{\circ}$ incline treadmill; $12 \mathrm{~m} / \mathrm{min} ; 50 \mathrm{~min} /$ day) was started $24 \mathrm{~h}$ after induction of unilateral tendinopathy and remained for 20 days. At 3, 7, 14 and 21 days after lesion induction, three rats from each group were euthanized and the tendons were collected for histological and morphometric analyses. There was no difference among groups or among times for the characteristics hemorrhage ( $\mathrm{p}=0.4154)$, fibrinous adhesion formation $(p=0.0712)$, and organization of collagen fibers $(p=0.2583)$ and of the connective tissue $(p=0.1046)$. For these groups, regardless of the time, eccentric exercise led to epitenon thickening ( $p=0.0204)$, which was lower in the group treated with laser therapy. Histological analysis revealed differences $(p=0.0032)$ in the number of inflammatory cells over time. They were more numerous in the group that only exercised. This result was confirmed by morphometric analysis, which showed a significant interaction (groups $\mathrm{x}$ time) for this characteristic. Eccentric exercise increased $(\mathrm{p}=0.0014)$ the inflammatory infiltrate over time (3 and 21 days). However, association with laser therapy reduced inflammatory reaction. On the other hand, the combination of the treatments increased angiogenesis in morphometric $(p=0.0000)$ and histological $(p=0.0006)$ analyses compared with the other groups, while the isolated application of low-level laser reduced this characteristic over time. Animals maintained at rest presented the lowest amount $(\mathrm{p}=0.0000)$ of fibroblasts, according to the morphometric analysis. However, histological evaluation showed a significant group $\mathrm{x}$ time interaction $(\mathrm{p}=0.0024)$. Greater amounts of fibroblasts were observed in groups $\mathrm{E}$, $\mathrm{L}$ and $\mathrm{LE}$ on the $7^{\text {th }}, 14^{\text {th }}$ and $21^{\text {st }}$ days, respectively. The animals that received laser therapy and were exercised showed a greater $(p=0.0000)$ amount of collagen fibers over time.
\end{abstract}

\footnotetext{
${ }^{1}$ Received on May 8, 2015.

Accepted for publication on December 10, 2015.

2 Departamento de Veterinária, Universidade Federal de Viçosa (UFV), Avenida Peter Henry Rolfs s/n, Campus Universitário, Viçosa, MG 36570900, Brazil.*Autor para correspondência: msouza@ufv.br

${ }^{3}$ Médico, Prevent - Laboratório de Anatomia Patológica e Citopatologia, Rua Benjamin Araújo 56, sala 110, Centro, Viçosa, MG 36570-000, Brazil. E-mail: tmjc@terra.com.br

${ }^{4}$ Mestranda do Departamento de Veterinária, UFV, Campus Universitário, Viçosa, MG 36570-900, Brazil. E-mail: micheline.silva@ufv.br
}

\footnotetext{
${ }^{5}$ Graduando do Departamento de Veterinária, UFV, Avenida Peter Henry Rolfs s/n, Campus Universitário, Viçosa, MG 36570-900, Brazil. Bolsista PIBIC-CNPq. E-mail: julio.crepaldi@ufv.br

${ }^{6}$ Departamento de Estatística, UFV, Avenida Peter Henry Rolfs s/n, Campus Universitário, Viçosa, MG 36570-900, Brazil. E-mail: chos@ufv.br

${ }^{7}$ Instituto Viçosense de Ensino e Pesquisa, Faculdade de Viçosa (FDV), Rua Dr. Milton Bandeira 380, Centro, Viçosa, MG 36570-000, Brazil. E-mail: garciasslr@yahoo.com.br

${ }^{8}$ Departamento de Educação Física, UFV, Avenida Peter Henry Rolfs s/n, Campus Universitário, Viçosa, MG 36570-900, Brazil. E-mail: anatali@ufv.br
} 
Laser therapy at a dose of $3 \mathrm{~J}$ and at a wavelength of $904 \mathrm{~nm}$, starting $24 \mathrm{~h}$ after surgical induction of tendinopathy in Wistar rats, is suitable for angiogenesis and prevention of tendon thickening, which can be associated with the intensity of inflammatory process. When associated with eccentric exercise, the therapy has the advantage of increasing the amount of collagen fibers, reducing fibrinous adhesions and inflammatory infiltrate, despite prolonging angiogenesis. Therefore, eccentric exercise performed concomitantly with laser therapy improves the histological properties of the injured tendon.

INDEX TERMS: Physical activity, treadmill walking, laser, common calcaneal tendon, tendinopathy.

RESUMO.- [Análise histomorfométrica do tendão calcanear comum de ratos Wistar tratado com laserterapia e exercício excêntrico.] 0 laser de baixa potência é recomendado para o tratamento das tendinopatias apesar dos resultados contraditórios no que se refere a dose de energia ideal, comprimento de onda e tempo de aplicação. 0 objetivo desse estudo foi avaliar os efeitos da laserterapia e do exercício excêntrico na tendinopatia do tendão calcanear comum de ratos Wistar. Foram utilizados 48 ratos machos adultos. Os animais foram distribuídos aleatoriamente em quatro grupos ( $\mathrm{L}=$ laser; $\mathrm{E}=$ =xercício excêntrico; $\mathrm{LE}=$ laser e exercício excêntrico, e $\mathrm{R}=$ repouso). Após $24 \mathrm{~h}$ da indução de tendinopatia unilateral, foi iniciada laserterapia $\left(904 \mathrm{~nm} / 3 \mathrm{~J} / \mathrm{cm}^{2}\right)$ e/ou exercício excêntrico (caminhada em declive; esteira com $15^{\circ}$ de inclinação; $12 \mathrm{~m} / \mathrm{min} ; 50 \mathrm{~min} /$ dia) que permaneceu por 20 dias. Aos 3, 7, 14 e 21 dias após indução da lesão, três ratos de cada grupo foram submetidos à eutanásia, e os tendões foram obtidos para análises histológica e morfométrica. Não houve diferença entre grupos nem entre tempos nas características hemorragia ( $p=0,4154)$, formação de aderência fibrinosa $(p=0,0712)$ e organização das fibras colágenas $(p=0,2583)$ e do tecido conjuntivo $(p=0,1046)$. Considerando os grupos, independentemente do tempo, foi observado que o exercício excêntrico ocasionou espessamento do epitendão $(p=0,0204)$, que foi menor no grupo submetido à laserterapia. A análise histológica revelou diferença $(\mathrm{p}=0,0032)$ na quantidade de células inflamatórias ao longo do tempo, sendo observado em maior quantidade no grupo apenas exercitado. Esse resultado foi confirmado pela análise morfométrica, que demonstrou haver interação significativa (grupos $\mathrm{x}$ tempo) nessa característica, na qual o exercício excêntrico aumentou $(\mathrm{p}=0,0014)$ o infiltrado inflamatório ao longo do tempo ( 3 e 21 dias), porém, quando associado à laserterapia, ocorreu redução da reação inflamatória. Por outro lado, a associação dos tratamentos ocasionou maior angiogênese observada nas análises morfométrica $(p=0,0000)$ e histológica $(\mathrm{p}=0,0006)$, quando comparada com os demais grupos, enquanto a aplicação isolada do laser de baixa potência reduziu essa característica ao longo do tempo. Os animais mantidos em repouso foram os que apresentaram menor $(p=0,0000)$ quantidade de fibroblastos, na análise morfométrica, porém na avaliação histológica foi observada interação significativa entre grupo e tempo $(p=0,0024)$. Maior quantidade de fibroblastos foi observada nos grupos E, L e LE, no $7^{\circ}$, $14^{\circ}$ e $21^{\circ}$ dias, respectivamente. Os animais que receberam laserterapia e foram exercitados apresentaram maior $(\mathrm{p}=0,0000)$ quantidade de fibras colágenas ao longo do tempo. A laserterapia na dose de $3 \mathrm{~J}$ e compri- mento de onda de $904 \mathrm{~nm}$, iniciada $24 \mathrm{~h}$ após indução cirúrgica de tendinopatia em ratos Wistar é adequada para angiogênese e para evitar o espessamento do tendão, que pode estar relacionado com a intensidade do processo inflamatório. Quando associada ao exercício excêntrico, a terapia apresenta a vantagem de aumentar a quantidade de fibras colágenas, reduzir a aderência fibrinosa e infiltrado inflamatório, apesar de prolongar a angiogênese. Portanto, o exercício excêntrico realizado concomitantemente com a laserterapia melhora as propriedades histológicas do tendão lesionado.

TERMOS DE INDEXAÇÃO: Atividade física, caminhada em esteira, laser, tendão de Aquiles, tendinopatia.

\section{INTRODUCTION}

Until recently, the term tendinitis had been used for acute and chronic tendon abnormalities, but it suggested the presence of an inflammatory process. However, while some studies revealed the coexistence of inflammation and degenerative changes in this condition (Andress \& Murrell, 2008), others showed little or no inflammation (Alfredson et al. 2000, Soslowsky et al. 2000). In addition, histological studies have revealed abnormal tissue repair and degeneration. Thus, the term tendinopathy started to be used by some researchers to define several painful conditions affecting the tendons (tendinitis, tendinosis), which are accompanied by pain, swelling and reduced performance (Alfredson 2003, Maffulli, et al. 2003, Wang et al. 2006).

Tendinopathy is highly prevalent both in athletes and sedentary people. Warden (2007) reports that $14 \%$ of elite athletes may be affected by the disease, whose recovery time can range from three to six months. Histologically, it may present collagen disorganization, increased number of cells, round fibroblast nuclei (Glazebrook et al. 2008), increased vascularity (Khan et al. 1999) and of glycosaminoglycans, which can be observed in Alcian Blue staining (Movin et al. 1997).

Conventional treatments for tendinopathy were initially aimed at reducing inflammation and providing pain relief, but the results were not always satisfactory. To be considered effective, therapies must reduce acute inflammation and provide tissue repair within a short period of time (Fillipin et al. 2005). The low-level laser therapy has been used for the treatment of musculotendinous and osteoarticular disorders because of its analgesic and anti-inflammatory effects and ability to stimulate collagen synthesis (Dogan et al. 2010), besides growth factors, which accelerate tissue repair (Salate et al. 2005), with improved struc- 
tural organization of the collagen fibers along the tendon longitudinal axis (Arruda et al. 2007). In eccentric exercise, the muscle under contraction is stretched while producing a force. This force is not sufficient to withstand the imposed external load, and the elongation of the tensioned fibers results in important changes in the muscle-tendon unit (Frick 2010, Isner-Horobeti et al. 2013).

The concomitant use of laser and controlled eccentric exercise may provide a better response to the therapy, as it can promote fibroblast activity, realignment of collagen fibers, and reduced chances of tissue adhesion, as well as faster recovery of the tendon (Fillipin et al. 2005, Salate et al. 2005, Bjordal et al. 2008). Nevertheless, few experiments deal with this kind of association. This study is based on the hypothesis that the combination of laser therapy and controlled physical activity results in a faster and more organized repair process in a tendon with histological characteristics more similar to those of a healthy tendon. Therefore, the present work aimed to evaluate the response to gallium arsenide (GaAs) low-level laser therapy associated with the eccentric exercise downhill treadmill walking in induced tendinopathy of the Achilles tendon of Wistar rats, through histopathological and morphometric analyses.

\section{MATERIALS AND METHODS}

This study was approved by the Ethics Committee of Animal Use of Universidade Federal de Viçosa (Document no. 108/2011), and the assays were conducted in accordance with the Veterinary Professional Ethics Code, the Ethical Principles for Animal Research established by Brazilian Society of Animal Science Laboratory and the current Brazilian legislation.

Forty-eight adult male Wistar rats (Rattus Norvegicus), aged between 12 and 14 weeks (13.02 \pm 0.83 ), and with body weight ranging from 300 to $350 \mathrm{~g}(325 \pm 18.76)$, were used. Only animals with physical integrity of locomotor systems were included in the study, determined after physical examination, in which behavior tests were carried out for evaluation of sensitivity to pain and locomotion capacity (Table 1).

Abnormalities in "spontaneous" behavior related to sensitivity to pain were evaluated by a subjective scale ranging from 0 to 5, according to the protocol used by Attal et al. (1990), with some modifications (reclassification of scores and more details on the characteristics evaluated). Locomotor capacity was assessed using scores that ranged from 0 to 12 , according to the protocol described by Silva (2008), in which the higher the score the closer the animal was to normality. The evaluation was conducted through the observation of the movement of hindlimbs and gait; in other words, the deambulation of the animals in spontaneous locomotion. Initially, the animals were individually placed in a $1.5 \mathrm{~m}$ long and $0.5 \mathrm{~m}$ wide space for observation of gait (including lameness). Subsequently, they underwent a more specific evaluation with wooden bars. For this, six $1 \mathrm{~m}$ long bars with widths of $7.7 \mathrm{~cm}, 6.7 \mathrm{~cm}, 5.7 \mathrm{~cm}, 4.7 \mathrm{~cm}, 3.7 \mathrm{~cm}, 2.7 \mathrm{~cm}$ and $1.7 \mathrm{~cm}$ were used. All rats walked twice along each bar, starting from the widest to the narrowest one. The animals were housed in individual cages for one week for acclimatization to conditions of approximately $26^{\circ} \mathrm{C}$, and were maintained at a $12 \mathrm{~h}$ daily photoperiod. All rats moved freely inside the cage and received industrial ration, and water ad libitum.

The rats were randomly distributed into four groups (L, E, LE and R). Each of them contained twelve rats, and three animals were used at each stage of the study. Group "L" was composed of animals subjected to laser therapy, whereas group "E" was subjected to the eccentric exercise treadmill walking. Animals from group "LE" underwent both laser therapy and treadmill walking, whereas group " $\mathrm{R}$ " rested throughout the healing process of the tendons. The animals were identified by a numerical sequence on the tail, according to the group they belonged to. The rats of groups $\mathrm{E}$ and $\mathrm{R}$ were handled as if they were going to receive radiation, but the equipment remained disconnected.

The Achilles tendon to be subjected to unilateral tendinopathy was selected randomly. In the preparation for surgical lesion induction, all the rats were subjected to fasting $(2 \mathrm{~h})$ and water deprivation $(1 \mathrm{~h})$ before the anesthetic procedure, which was performed according to the protocol described by Silva et al. (2013).

The limbs were clipped and prepared aseptically with $1 \%$ iodine-povidine. After longitudinal skin incision of the right or left hindlimb (chosen at random), the Achilles tendon was exposed. The lesion was induced in the middle point between the myotendinous junction and tendon insertion on the calcaneal bone, according to Silva et al. (2013), by tendon whole-thickness transversal compression for $10 \mathrm{~s}$, using Halsted forceps (the second ratchet), followed by 10 proximal-distal ward scarifications of the tendon fibers using a scalpel blade. Skin synthesis was performed in a Wolff type continuous pattern using 3-0 Nylon.

Still under anesthesia, the animals received a single dose (40 mg/kg intramuscularly) of enrofloxacin. Morphine $(3 \mathrm{mg} / \mathrm{kg}$, subcutaneously) was also administered every $6 \mathrm{~h}$ for a period of $12 \mathrm{~h}$. At the end of the surgical procedure, the animals were maintained in a warm environment at a temperature of approximately $27^{\circ} \mathrm{C}$ until their complete recovery from the anesthetic effect. During the postoperative period, the wounds were cleaned daily with gauze soaked in running water.

The animals from groups L and LE received GaAs low-level laser therapy. The application was carried out in a single area and in pulse mode for nine seconds/day, with the use of laserpulse equipment (Ibramed Indústria Brasileira de Equipamentos Médicos Ltda), 904nm wavelength, 3J/ $\mathrm{cm}^{2}$ energy density and $100 \mathrm{~mW} / \mathrm{cm}^{2}$ power. The treatment began $24 \mathrm{~h}$ after injury induction and was applied daily for 20 days. During laser application, the animals were immobilized manually and positioned in ventral decubitus, according to the protocol used by Xavier et al. (2010). The device was positioned perpendicularly to the injury, and the radiation was always performed at the same time of the day, with $24 \mathrm{~h}$ intervals between applications, as proposed by Taciro et al. (2007) and Silva et al. (2011). As a security measure, the professionals used laser goggles (Ibramed Indústria Brasileira de Equipamentos Médicos Ltda, Amparo, SP, Brazil) for protection against radiation.

Animals from groups $\mathrm{E}$ and LE were subjected to daily controlled eccentric exercise, starting $24 \mathrm{~h}$ after tendinopathy induction. During three weeks, a treadmill (Insight Pesquisa e Ensino Ltda) walking protocol modified from that described by Nakamura et al. (2008), who used eccentric exercise (downhill treadmill running) for a longer period (60min) and at a higher speed $(15 \mathrm{~m} / \mathrm{min})$, was adopted. With the purpose of prior adaptation to the exercise, the animals were exercised for seven consecutive days before surgical injury induction. The speed was set to $12 \mathrm{~m} / \mathrm{min}, 50 \mathrm{~min} /$ day, during both the adaptation and experimental periods. The treadmill remained at $15^{\circ}$ incline, and the animals walked downhill, i.e., in a direction opposite to the traditional one. The eccentric exercise was performed in a quiet environment, with little lighting, and at a room temperature of approximately $25^{\circ} \mathrm{C}$.

After tendinopathy induction and during the treatments, the rats were subjected to physical evaluation of the site of the injury 
Table 1. Behavior tests based on sensitivity to pain and locomotion capacity

Score Physical evaluation

Sensitivity to pain (according to Attal et al. 1990)

0 Absent (distal region of limb - paw - the operated paw is pressed normally on the floor)

1 Discrete (distal region of limb - paw - the paw rests lightly on the floor and the toes are in a ventroflexed position)

2 Discrete to moderate (only the internal edge of the paw is pressed on the floor)

3 Moderate (only the talocalcaneal region - heel - of the paw is pressed on floor; hind paw is in an inverted position)

4 Moderate to intense (the whole distal region - paw - is elevated)

5 Intense (the animal licks the operated paws)

Locomotion capacity (according to Silva 2008)

0 Absence of hindlimb movement; non-weight-bearing

1 Subtle movement, disconnected from the hindlimb; non-weight-bearing

2 Visible movement of hindlimb; non-weight-bearing

3 Supports load in hindlimb, but walks with accentuated deficit

4 Walk with moderate difficulty

5 Walk with a discrete deficit, and cannot walk on $7.7 \mathrm{~cm}$ wide bar

6 Normal walk or discrete deficit, and can walk on $7.7 \mathrm{~cm}$ wide bar

7 Can walk on $6.7 \mathrm{~cm}$ wide bar

8 Can walk on $5.7 \mathrm{~cm}$ wide bar

9 Can walk on $4.7 \mathrm{~cm}$ wide bar

10 Can walk on $3.7 \mathrm{~cm}$ wide bar

11 Can walk on $2.7 \mathrm{~cm}$ wide bar

12 Can walk on $1.7 \mathrm{~cm}$ wide bar

and to the behavior tests described in Table 1 . The first examination was performed $12 \mathrm{~h}$ after surgery, and the others at every three days, for 20 days. Twenty-four observations were performed during the behavioral tests, i.e., eight evaluations were conducted using three animals (replicates) in each group. Local examination consisted of evaluation of surgical wound. Initially, it was checked whether there were signs of inflammation or infection in the site of the surgery.

Fragments of tendons were obtained during the inflammatory and proliferative phases of the tendon repair process. For this, three rats from each group were randomly selected to be euthanized 3, 7, 14 and 20 days after the beginning of the treatment, according to the protocol described by Carvalho et al. (2006), with modifications in the number of days of assessment.

The euthanasia procedure was carried out by using sodium thiopental $(100 \mathrm{mg} / \mathrm{kg}$, intraperitoneally). After euthanasia and skin incision, the Achilles tendon was exposed. At the occasion, a possible existence of tissue adhesions between tendon and the skin and/or adjacent tissues was evaluated. The tendons were collected in their full length, from the myotendinous junction to the insertion in the calcaneal bone, and fixed in 10\% neutral buffered formalin for $48 \mathrm{~h}$. The samples were subjected to routine methods for histopathology. The sections (longitudinal plane) were cut at a thickness of $4 \mu \mathrm{m}$ and stained using the following techniques: hematoxylin and eosin (HE), Picrosirius Red and Masson's trichrome.

The histological and morphometric analyses were conducted by using a light microscope (Olympus BX50) coupled to a photographic camera (Olympus QColor 3) with a 20x objective lens and a 10x ocular lens. A polarized light filter was coupled to the microscope to observe the Picrosirius Red stained samples. The analyses were conducted by three observers who were blinded to the treatments to which the sections belonged.

The cellular characterization and the organization of tendon matrix were determined in fragments stained with HE. The analysis followed the criteria described by Orhan et al. (2004) with some modifications. Assessments were performed for the formation of fibrinous tissue adhesions, organization including the parallelism of the collagen fibers, epitenon thickening, as well as the presence of angiogenesis, leukocytes and fibroblasts. Hemorrhage was also evaluated, defined by the presence of erythrocytes in the tissue. The scoring system used to assess these histological characteristics ranged from 0 to 4 ( 0 : absent, 1 : mild, 2: moderate, 3: moderate to intense, and 4: intense).

A morphometric analysis was used to quantitatively assess the type of inflammatory infiltrate, angiogenesis, collagen fibers, fibroblasts and type I and III collagen fibers. For this purpose, ten photomicrographs were randomly obtained for each sample with a 20x objective lens and placed under a point-counting grid with 400 intersections provided by Microsoft PowerPoint software, as performed by Zandim et al. (2013), with modifications. The mean values for each variable were obtained from the counts in the ten images.

Masson's trichrome staining was used to help in the assessment of both the vascularization and organization of the connective tissue, by using the same scoring system previously described, whereas Picrosirius Red staining was used to evaluate the organization of the collagen fibers and to provide information regarding the types of collagen observed (I and III).

The experiment was arranged in a completely randomized design with four treatments (groups L, E, LE and R) and three replicates (animals), evaluated at 3, 7, 14 and 21 days after injury induction. The number of rats per group was the minimum necessary to conduct the research, allowing inferential analyses with an appropriate number of degrees of freedom for the residuals of the analysis of variance (ANOVA). Data were initially subjected to descriptive analysis, and Lilliefors and Cochran tests were conducted for the assessment of normality and homogeneity of variance, respectively. ANOVA was used to check the effects of the treatments on the following aspects: physical (locomotion capacity), macroscopic (presence of fibrous adhesion), histological (hemorrhage, fibrinous tissue adhesions, organization of collagen fibers, epitenon thickening, angiogenesis, presence of leukocytes, fibroblasts and organization of connective tissue) and morphometric (collagen fibers, fibroblasts, inflammatory infiltrate, angiogenesis and type I and III collagen fibers). The treatments were compared by Tukey's test at 5\% probability. A line graph was created, over time, for the characteristic locomotion capacity, as well as tables with mean values and standard deviations for histological and morphometric characteristics. The analyses were carried out using the Statistica 12 software system, 2013 (www.statsoft.com).

\section{RESULTS}

Throughout the experimental period, no sign of infection was observed in any limb. In the physical evaluation performed $12 \mathrm{~h}$ after induction of tendinopathy, increased local temperature was detected in the tendons related to groups $\mathrm{L}(\mathrm{n}=4,33.3 \%), \mathrm{R}(\mathrm{n}=2,16.6 \%), \mathrm{E}(\mathrm{n}=1,8.3 \%)$ and $\mathrm{LE}(\mathrm{n}=1$, $8.3 \%$ ), which lasted up to $72 \mathrm{~h}$.

During the evaluation of sensitivity to pain, the rats presented no apparent signs of discomfort, and maintained normal hindlimb posture. Therefore, all animals received score 0 (absent) in the classification of sensitivity to pain adopted in the study. Conversely, the locomotion capacity evaluation revealed mild lameness during deambulation in open field in all animals up to $72 \mathrm{~h}$ after tendinopathy induction. A difference $(p=0.0008)$ was detected among groups for the locomotion capacity. The animals maintained at rest showed less locomotion capacity $(10.23 \pm 2.12)$ 


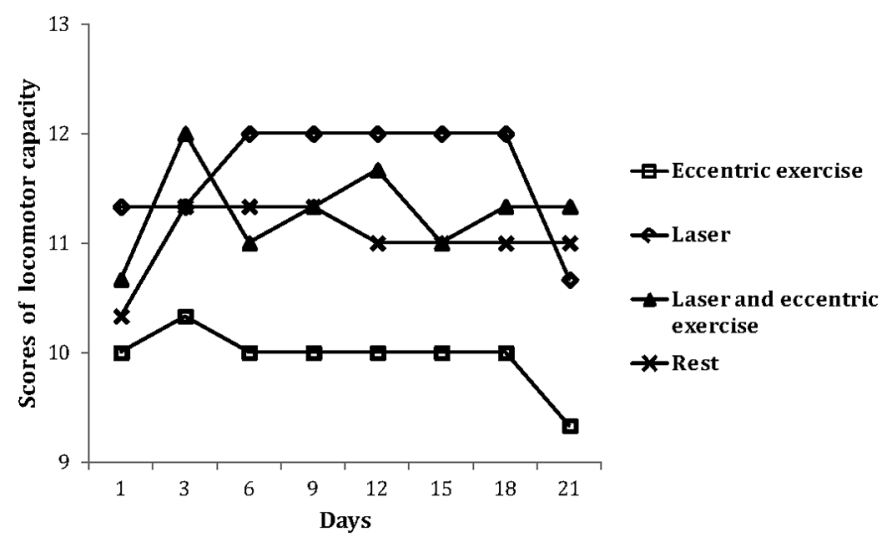

Fig.1. Evolution of the mean scores obtained from the assessment of locomotion capacity over time. In most studied periods, the group maintained at rest showed less locomotion capacity, unlike the group subjected to eccentric exercise only.

than those of the other groups, with mean values and standard deviations of $10.73 \pm 1.22$ (L), $11.25 \pm 0.99$ (LE) and $11.37 \pm 0.92$ (E). In the physical evaluation performed on day 21 , only one animal from each group was able to move on the $1.7 \mathrm{~cm}$ bar. Fig. 1 shows the evolution of this characteristic over time. The lowest response was obtained from the animals that remained at rest.

The macroscopic evaluation showed no fibrous adhesion in the rats euthanized on day 3 , but the tendons presented pinkish color. One rat from group L and another from group LE showed mild local hemorrhage, and there was no sign of initial healing in the surgical incision. One week after injury induction, adhesion was formed between the tendon and adjacent tissues in only one animal from group L and in another from group R. The tendons presented grayish color and soft appearance. The tendons of the rats euthanized in two and three weeks seemed healthy and had light yellow color.

In the general histological observation of the sections stained with HE, Masson's trichrome and Picrosirius Red, it was possible to distinguish the injured from the healthy area. These areas differed in size and characteristics, depending on the inflammatory or proliferative phases. The injured areas were more noticeable in the periphery of the tendon.

The histological sections evaluated on the third day after lesion induction showed mild hemorrhage, with moderate to intense fibrinous tissue adhesions formation, characterized by the presence of fibrin, besides epitenon thickening. The inflammatory infiltrate composed predominantly of polymorphonuclear leukocyte was also observed in higher amount than that of the other times evaluated. Fibroblasts with round/plump nuclei (blast cells) were present, although in mild quantity. Formation of new vessels, tissue disorganization and lack of parallelism of the collagen fibers were also observed.

In the first week, it was still possible to observe mild hemorrhage as well as a thicker epitenon due to the local accumulation of inflammatory cells. Leucocyte occurrence remained moderate, with a significant amount of neutrophils. Increased angiogenesis and increased amounts of fibroblasts were also found. At that moment, the collagen
Table 2. Semiquantitative histological evaluation (mean \pm standard deviation) of the characteristics hemorrhage, adhesion formation, epitenon thickening and collagen fiber organization, obtained by the scoring system to assess the tendon repair process at different times

\begin{tabular}{ccccc}
\hline Time (days) & Rest & $\begin{array}{c}\text { Eccentric } \\
\text { exercise }\end{array}$ & Laser & $\begin{array}{c}\text { Laser plus } \\
\text { eccentric exercise }\end{array}$ \\
\hline Hemorrhage & & & & \\
3 & $1.33 \pm 0.58$ & $1.00 \pm 0.00$ & $1.00 \pm 0.00$ & $1.00 \pm 1.00$ \\
7 & $1.00 \pm 1.00$ & $0.67 \pm 0.58$ & $0.33 \pm 0.58$ & $1.00 \pm 0.00$ \\
14 & $0.00 \pm 0.00$ & $0.00 \pm 0.00$ & $0.33 \pm 0.58$ & $0.00 \pm 0.00$ \\
21 & $0.67 \pm 1.50$ & $0.00 \pm 0.00$ & $0.00 \pm 0.00$ & $0.33 \pm 0.58$ \\
Mean \pm SD & $0.75 \pm 0.87$ & $0.42 \pm 0.51$ & $0.42 \pm 0.51$ & $0.58 \pm 0.67$ \\
Adhesions & & & & \\
3 & $3.33 \pm 1.15$ & $3.00 \pm 1.73$ & $3.67 \pm 0.58$ & $2.67 \pm 1.15$ \\
7 & $3.00 \pm 1.00$ & $1.33 \pm 0.58$ & $1.67 \pm 1.15$ & $2.00 \pm 1.00$ \\
14 & $1.33 \pm 0.58$ & $1.33 \pm 0.58$ & $2.33 \pm 0.58$ & $0.67 \pm 0.58$ \\
21 & $2.00 \pm 1.00$ & $0.67 \pm 0.58$ & $1.67 \pm 0.58$ & $1.00 \pm 1.00$ \\
Mean \pm SD & $2.42 \pm 1.16$ & $1.58 \pm 1.24$ & $2.33 \pm 1.07$ & $1.58 \pm 1.31$ \\
Epitenon thickening & & & \\
3 & $2.00 \pm 0.00$ & $1.67 \pm 0.58$ & $0.33 \pm 0.58$ & $2.00 \pm 0.00$ \\
7 & $0.00 \pm 0.00$ & $1.67 \pm 058$ & $0.67 \pm 0.58$ & $1.33 \pm 1.15$ \\
14 & $0.67 \pm 1.15$ & $0.33 \pm 0.58$ & $0.00 \pm 0.00$ & $0.00 \pm 0.00$ \\
21 & $0.33 \pm 0.58$ & $1.33 \pm 1.15$ & $0.67 \pm 1.15$ & $1.33 \pm 0.58$ \\
Mean \pm SD & $0.75 \pm 0.97 \mathrm{AB}$ & $1.75 \pm 0.87 \mathrm{~A}$ & $0.42 \pm 0.67 \mathrm{~B}$ & $1.17 \pm 0.94 \mathrm{AB}$ \\
Collagen organization & & & \\
3 & $0.00 \pm 0.00$ & $1.00 \pm 0.00$ & $0.33 \pm 0.58$ & $1.00 \pm 0.00$ \\
7 & $1.67 \pm 0.58$ & $2.00 \pm 0.00$ & $1.00 \pm 0.00$ & $1.67 \pm 1.15$ \\
14 & $1.67 \pm 0.58$ & $1.67 \pm 0.58$ & $2.33 \pm 1.15$ & $2.33 \pm 0.58$ \\
21 & $1.67 \pm 0.58$ & $2.00 \pm 2.00$ & $1.67 \pm 0.58$ & $2.33 \pm 1.55$ \\
Mean \pm SD & $1.25 \pm 0.87$ & $1.67 \pm 0.98$ & $1.33 \pm 0.94$ & $1.83 \pm 0.87$ \\
\hline
\end{tabular}

Means in the row followed by at least one common letter do not differ by Tukey's test $(p>0.05) . S D=$ standard deviation.

Table 3. Semiquantitative histological evaluation (mean \pm standard deviations) of the characteristics fibroblast activity, presence of leukocytes, angiogenesis and connective tissue organization, obtained by the scoring system to assess the tendon repair process at different times

\begin{tabular}{ccccc}
\hline Time (days) & Rest & $\begin{array}{c}\text { Eccentric } \\
\text { exercise }\end{array}$ & Laser & $\begin{array}{c}\text { Laser plus } \\
\text { eccentric exercise }\end{array}$ \\
\hline Fibroblast activity & & & \\
3 & $0.33 \pm 0.58$ & $0.67 \pm 0.58$ & $1.33 \pm 0.58$ & $1.00 \pm 0.00$ \\
7 & $0.33 \pm 0.58 \mathrm{~B}$ & $2.00 \pm 0.00 \mathrm{~A}$ & $1.00 \pm 0.00 \mathrm{AB}$ & $1.67 \pm 0.58 \mathrm{~A}$ \\
14 & $1.00 \pm 0.00 \mathrm{~B}$ & $1.67 \pm 0.58 \mathrm{~B}$ & $3.00 \pm 0.00 \mathrm{~A}$ & $1.67 \pm 0.58 \mathrm{~B}$ \\
21 & $1.33 \pm 0.58 \mathrm{~B}$ & $1.67 \pm 0.58 \mathrm{AB}$ & $2.00 \pm 0.00 \mathrm{AB}$ & $2.67 \pm 1.58 \mathrm{~A}$ \\
Mean \pm SD & $0.75 \pm 0.62$ & $1.50 \pm 0.67$ & $1.83 \pm 0.83$ & $1.75 \pm 0.75$ \\
Presence of leukocytes & & & \\
3 & $2.33 \pm 0.58$ & $3.00 \pm 0.00$ & $2.67 \pm 0.58$ & $2.00 \pm 0.00$ \\
7 & $1.67 \pm 0.58$ & $2.67 \pm 0.58$ & $2.00 \pm 0.00$ & $1.67 \pm 0.58$ \\
14 & $1.33 \pm 0.58$ & $1.67 \pm 0.58$ & $1.67 \pm 0.58$ & $1.00 \pm 0.00$ \\
21 & $0.67 \pm 0.58$ & $1.33 \pm 2.00$ & $1.00 \pm 0.00$ & $0.67 \pm 0.58$ \\
Mean \pm SD & $1.50 \pm 0.80 \mathrm{~B}$ & $2.17 \pm 0.94 \mathrm{~A}$ & $1.83 \pm 0.72 \mathrm{AB}$ & $1.33 \pm 0.65 \mathrm{~B}$ \\
Angiogenesis & & & & \\
3 & $1.33 \pm 0.58$ & $1.67 \pm 1.53$ & $1.33 \pm 0.58$ & $1.67 \pm 0.58$ \\
7 & $1.33 \pm 0.58$ & $2.67 \pm 0.58$ & $1.00 \pm 0.00$ & $2.67 \pm 0.58$ \\
14 & $2.33 \pm 0.58$ & $2.33 \pm 0.58$ & $1.67 \pm 0.58$ & $3.33 \pm 0.58$ \\
21 & $1.33 \pm 0.58$ & $1.33 \pm 0.58$ & $1.67 \pm 0.58$ & $2.67 \pm 0.58$ \\
Mean $\pm \mathrm{SD}$ & $1.58 \pm 0.67 \mathrm{~B}$ & $2.00 \pm 0.67 \mathrm{AB}$ & $1.42 \pm 0.51 \mathrm{~B}$ & $2.58 \pm 0.79 \mathrm{~A}$ \\
Connective tissue organization & & & \\
3 & $0.00 \pm 0.00$ & $0.67 \pm 0.58$ & $0.33 \pm 0.58$ & $0.33 \pm 0.58$ \\
7 & $0.00 \pm 0.00$ & $2.00 \pm 0.00$ & $1.67 \pm 0.58$ & $1.67 \pm 1.15$ \\
14 & $2.33 \pm 0.58$ & $2.00 \pm 0.00$ & $1.67 \pm 0.58$ & $2.67 \pm 0.58$ \\
21 & $2.33 \pm 0.58$ & $3.33 \pm 1.15$ & $2.33 \pm 0.58$ & $2.33 \pm 0.58$ \\
Mean $\pm \mathrm{SD}$ & $1.42 \pm 1.08$ & $2.00 \pm 1.13$ & $1.50 \pm 0.90$ & $1.75 \pm 1.14$
\end{tabular}

Means in the row followed by at least one common letter do not differ by Tukey's test $(\mathrm{p}>0.05)$. SD = standard deviation. 
fibers were still disorganized, without parallelism. In the evaluation performed in the second week after injury induction, large amounts of plump fibroblasts and collagen fibers with mild organization were observed, as well as increased vascularization and a mild amount of inflammatory cells. Finally, in the third week, there was already a sign of tissue remodeling, characterized by a reduced amount of inflammatory cells, tendency to organization and parallelism of the collagen fibers, besides increased amount of spindle-shaped fibroblasts.

Mean and standard deviation values per group and per time referring to semiquantitative evaluation of the histological characteristics studied are shown in Tables 2 and 3 . The results of the morphometric analysis are shown in Table 4 . There was no difference $(\mathrm{p}=0.4154)$ among groups for hemorrhage nor tissue adhesion $(\mathrm{p}=0.0712)$ (Table 2). A mild amount of extravasated erythrocyte was observed in all groups on day 3 and in groups R and LE on day 7. In the histological evaluation performed on day 3 , groups R, E and $\mathrm{L}$ showed moderate to intense fibrinous tissue adhesions (Table 2), determined by the presence of fibrin (Fig.2a). One week after injury, the adhesion was rather variable. It was mild in groups $\mathrm{E}$ and $\mathrm{L}$, moderate in LE, and moderate to intense in group R. In the second week, the animals treated with laser therapy alone presented moderate adhesion, which was mild in groups $\mathrm{R}$ and $\mathrm{E}$, and absent in LE. In the rats euthanized in the third week, this characteristic was moderate in $\mathrm{R}$, mild in groups $\mathrm{L}$ and $\mathrm{LE}$, and considered absent in the group subjected to controlled physical activity.

Table 4. Morphometric evaluation (mean \pm standard deviations) of the characteristics collagen fibers, fibroblast activity, inflammatory infiltrate and angiogenesis, obtained at different times of the tendon repair process

\begin{tabular}{|c|c|c|c|c|}
\hline Time (days) & Rest & $\begin{array}{l}\text { Eccentric } \\
\text { exercise }\end{array}$ & Laser & $\begin{array}{l}\text { Laser plus } \\
\text { eccentric exercis }\end{array}$ \\
\hline \multicolumn{5}{|c|}{ Collagen fibers (\%) } \\
\hline 3 & $12.69 \pm 1.74$ & $21.84 \pm 6.56$ & $40.01 \pm 8.67$ & $52.62 \pm 33.24$ \\
\hline 7 & $21.46 \pm 9.90$ & $24.79 \pm 2.96$ & $48.85 \pm 12.31$ & $46.27 \pm 24.46$ \\
\hline 14 & $39.36 \pm 4.82$ & $26.04 \pm 7.96$ & $38.98 \pm 14.37$ & $53.54 \pm 744$ \\
\hline 21 & $28.47 \pm 18.93$ & $31.17 \pm 10.43$ & $34.33 \pm 18.46$ & $31.76 \pm 16.20$ \\
\hline Mean \pm SD & $25.50 \pm 13.85 \mathrm{~B}$ & $25.96 \pm 7.24 \mathrm{~B}$ & $40.54 \pm 13.07 \mathrm{AB}$ & $46.05 \pm 21.22 \mathrm{~A}$ \\
\hline \multicolumn{5}{|c|}{ Fibroblast activity (\%) } \\
\hline 3 & $1.10 \pm 0.70$ & $1.25 \pm 0.34$ & $2.97 \pm 0.41$ & $2.51 \pm 0.24$ \\
\hline 7 & $1.19 \pm 0.32$ & $3.73 \pm 1.33$ & $2.06 \pm 0.42$ & $2.31 \pm 0.34$ \\
\hline 14 & $1.85 \pm 1.37$ & $2.79 \pm 0.63$ & $3.29 \pm 0.78$ & $2.76 \pm 0.50$ \\
\hline 21 & $1.19 \pm 0.37$ & $1.80 \pm 0.89$ & $2.39 \pm 0.35$ & $2.56 \pm 0.33$ \\
\hline Mean \pm SD & $1.33 \pm 0.76 \mathrm{~B}$ & $2.39 \pm 1.24 \mathrm{~A}$ & $2.68 \pm 1.32 \mathrm{~A}$ & $2.54 \pm 0.35 \mathrm{~A}$ \\
\hline \multicolumn{5}{|c|}{ Inflammatory infiltrate (\%) } \\
\hline 3 & $0.64 \pm 0.10 \mathrm{~B}$ & $0.99 \pm 0.23 \mathrm{~A}$ & $0.78 \pm 0.33 \mathrm{AB}$ & $0.54 \pm 0.00 \mathrm{~B}$ \\
\hline 7 & $0.37 \pm 0.14$ & $0.66 \pm 0.32$ & $0.38 \pm 0.16$ & $0.35 \pm 0.17$ \\
\hline 14 & $0.12 \pm 0.05$ & $0.22 \pm 0.02$ & $0.18 \pm 0.11$ & $0.08 \pm 0.06$ \\
\hline 21 & $0.00 \pm 0.06 \mathrm{~B}$ & $0.33 \pm 0.08 \mathrm{~A}$ & $0.02 \pm 0.03 \mathrm{AB}$ & $0.00 \pm 0.00 \mathrm{~B}$ \\
\hline Mean \pm SD & $0.28 \pm 0.27$ & $0.55 \pm 0.36$ & $0.34 \pm 0.34$ & $0.24 \pm 0.24$ \\
\hline \multicolumn{5}{|c|}{ Angiogenesis (\%) } \\
\hline 3 & $1.35 \pm 0.94$ & $2.43 \pm 0.09$ & $1.21 \pm 0.38$ & $1.81 \pm 1.42$ \\
\hline 7 & $1.22 \pm 0.64$ & $3.80 \pm 2.03$ & $0.99 \pm 0.41$ & $2.75 \pm 3.20$ \\
\hline 14 & $2.15 \pm 0.54$ & $2.37 \pm 0.72$ & $1.66 \pm 1.37$ & $2.98 \pm 1.97$ \\
\hline 21 & $1.56 \pm 0.29 \mathrm{~B}$ & $1.51 \pm 0.60 \mathrm{~B}$ & $1.50 \pm 1.20 \mathrm{~B}$ & $5.04 \pm 4.24 \mathrm{~A}$ \\
\hline Mean \pm SD & $1.57 \pm 0.67 \mathrm{AB}$ & $2.53 \pm 1.28 \mathrm{AB}$ & $1.34 \pm 0.86 \mathrm{~B}$ & $3.15 \pm 2.78 \mathrm{~A}$ \\
\hline
\end{tabular}

Means in the row followed by at least one common letter do not differ by Tukey's test $(\mathrm{p}>0.05)$. SD = standard deviation.
A difference among groups $(\mathrm{p}=0.0204)$ was detected for the characteristic epitenon thickening (Table 2), which was lower and higher in the groups subjected to laser therapy and eccentric exercise, respectively. A moderate increase occurred on day 3 of assessment of groups R and LE. It was mild in group $\mathrm{E}$ and considered absent in $\mathrm{L}$. In the first week, only groups E and LE showed mild epitenon thickening, which was also mild on day 21.

There was no difference $(p=0.2583)$ among groups in the organization of collagen fibers, which was absent in group $\mathrm{R}$ and $\mathrm{L}$, and mild in the groups subjected to eccentric exercise ( $\mathrm{E}$ and $\mathrm{LE}$ ) on day 3 of assessment. This characteristic was considered moderate in rats exercised alone in the first week after tendinopathy induction, and mild in groups $\mathrm{R}$, $\mathrm{L}$ and LE. In the animals treated with laser with or without physical activity, this moderate organization was observed only in the second week (Fig.2b). Only the exercised rats showed moderate organization in the final assessment.

Picrosirius Red staining allowed the observation of the injured region, characterized by areas with little organization in the initial phase, but with a larger amount of type III collagen fibers at all times assessed. These fibers, identified in greenish color, were entangled with type I fibers, stained either yellow or red. This histochemical technique revealed areas in process of organization, with the presence of type I collagen fibers, found mainly in tendons treated with laser therapy, which in turn showed fiber bundles with better organization when associated with eccentric exercise.

The morphometric analysis revealed no difference $(p=0.2783)$ among groups or among times $(p=0.4804)$ for the amount of type I collagen fibers. However, these fibers were observed from the second week, and only in the group treated with laser therapy. This condition remained until the $21^{\text {st }}$ day. In groups of exercised rats ( $E$ and $L E$ ), these fibers were first observed in three weeks. The behavior of type III collagen fibers was quite variable, though no difference $(p=0.3052)$ was observed among groups or among times $(p=0.7617)$ for the amount of these fibers. They could be observed on the third day of the assessment, when the greatest amount was found in LE $(51.91 \pm 33.51)$, and the lowest value in group R $(12.94 \pm 1.20)$. At that time, the fibers were disorganized, with separate bundles. In the first week, the animals maintained at rest showed greater amount (43.78 \pm 38.87$)$, while a lower quantity was observed in the animals that performed only eccentric exercise $(18.57 \pm 9.64)$. In the second week, group LE $(53.51 \pm 7.36)$ showed the greatest amount of type III collagen fibers, while the rats under eccentric exercise alone $(17.12 \pm 7.55)$ continued to show the fewest amount. Three weeks after lesion induction, group L $(38.25 \pm 24.18)$ showed the highest values for this characteristic. These fibers can be easily observed 21 days after tendinopathy in animal of the group LE (Fig.2c).

Morphometric analysis of HE-stained samples (Table 4) reveled a higher amount $(p=0.0000)$ of collagen fibers over time in group LE, which was similar to group L. Although there was no difference among times $(\mathrm{p}=0.6797)$, the quantification of collagen fibers revealed that, on the $3^{\text {rd }}$ day, groups LE and R showed the greatest and lowest 

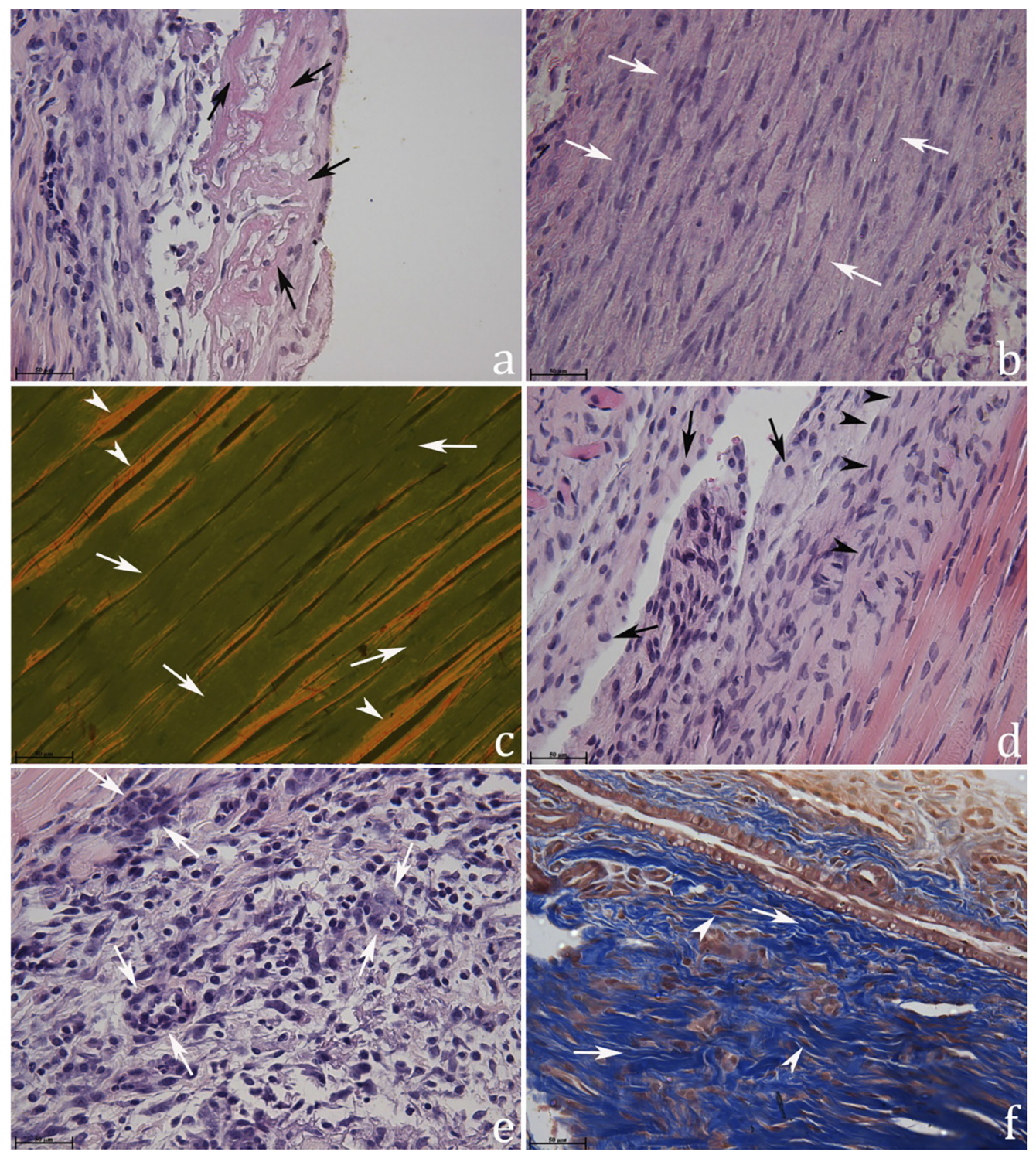

Fig.2. Photomicrography of the Achilles tendon of Wistar rats at different times of the repair process. (a) Fibrin network trapping intact and degenerate neutrophils (arrows) observed three days after lesion induction in the group maintained at rest. (b) Collagen fibers arranged moderately in parallel form (arrows), in an animal treated with laser and eccentric exercise, in the evaluation performed after two weeks. (c) Type III collagen fibers stained green (arrows), and type I stained reddish yellow (arrow head), present in animal exercised and treated with laser therapy, after 21 days of injury. (d) Section presenting transition area (healthy and injured), with the fibroblast proliferation in early organization, with few plump fibroblasts (arrows), and a higher amount in spindle shape (head of arrows), observed 21 days after tendinopathy induction in a rat treated with laser therapy only. (e) Angiogenesis (arrows) in animal subjected to eccentric exercise alone, observed three days after injury. (f) Moderate to intense organization of the connective tissue (arrows), with aligned fibroblasts (arrow head) arranged in parallel to the collagen fibers, observed in the group of animals submitted only to exercise. HE (a,b,d,e), Picrosirius Red (c), and Masson's trichrome (e), 200x magnification.

number of collagen fibers, respectively. On the $7^{\text {th }}$ day, the animals treated with laser showed a greater fiber content, but it was lower in rats maintained at rest. In the second week, group LE showed a higher amount of collagen fibers again, and this characteristic was lower in the group subjected to eccentric exercise alone. The rats maintained at rest and treated with laser presented, respectively, lower and higher amounts of collagen fibers at day 21, although not statistically different from the other groups.
There was a difference in the amount of fibroblasts $(\mathrm{p}=0.0000)$, considering the groups, but not among times $(\mathrm{p}=0.2305)$ (Table 4$)$, and it was lower in the group maintained at rest. On the third day, group L showed more plump fibroblasts. The amount was higher in groups $\mathrm{E}, \mathrm{L}$ and $\mathrm{LE}$ on the $7^{\text {th }}, 14^{\text {th }}$ and $21^{\text {st }}$ days, respectively. Figure $2 \mathrm{~d}$ refers to an image obtained 21 days after lesion induction in the tendon treated only with low-level laser. A similar result for this characteristic was obtained from the histological assessment on 
the $7^{\text {th }}, 14^{\text {th }}$ and $21^{\text {st }}$ days, when there was a significant interaction between group and time $(p=0.0024)$ (Table 3$)$.

There were also differences among groups for the characteristic leukocyte $(\mathrm{p}=0.0032)$ (Table 3$)$, for which the animals treated only with eccentric exercise showed more inflammatory infiltrate on the $3^{\text {rd }}, 7^{\text {th }}, 14^{\text {th }}$ and $21^{\text {st }}$ days, while those that received laser therapy associated with exercise presented less leukocyte infiltrate practically at all times evaluated. A similar result was obtained in the morphometric analysis. The amount of inflammatory infiltrate with significant $(\mathrm{p}=0.0014)$ interaction (group $\mathrm{x}$ time) occurred at 3 and 21 days, when this characteristic was higher in rats that only exercised (Table 4). However, it was not different from those tendons of animals, which received only the laser therapy. In the first evaluation, the infiltrate consisted mainly of degenerated neutrophils and few macrophages and eosinophils were observed.

The histological evaluation revealed differences $(p=0.0006)$ among groups for the characteristic angiogenesis (Table 3). The animals from groups LE and L showed, respectively, higher and lower formation of new blood vessels. At day 3, all groups showed mild angiogenesis, and a moderate grade was found in groups $E$ and LE on the $7^{\text {th }}$ day. It was from moderate to intense in group LE on day 14. In the last evaluation, conducted on day 21 , rats showed reduced angiogenesis, which was mild in groups $\mathrm{R}, \mathrm{E}$ and $\mathrm{L}$, and moderate in group LE. For all times assessed, morphometry indicated higher $(\mathrm{p}=0.0000)$ angiogenesis in group LE than in group L (Table 4). There was no difference between the evaluated times $(\mathrm{p}=0.7455)$, but on the third day, angiogenesis was more intense in groups E (Fig.2e) and LE, which persisted until the first week. In the second and third weeks, the group of animals that underwent laser therapy associated with eccentric exercise showed increased angiogenesis.

There was no difference $(\mathrm{p}=0.1046)$ among groups for the characteristic organization of connective tissue (Table 3 ), which was easily assessed in the Masson's trichrome-stained samples. For this staining, organization was absent on the $3^{\text {rd }}$ day in all groups. In the first week, the rats subjected to eccentric exercise showed moderate organization. It was mild in groups $\mathrm{L}$ and LE, and absent in R. In the second week, all groups showed moderate tissue organization, except L, in which this characteristic was mild. Only the group treated with eccentric exercise alone (Fig.2f) showed organization classified as moderate to intense in the third week.

\section{DISCUSSION}

Several methods of tendinopathy induction in rats are used for a better understanding of the disease and the effects of different therapies. The surgical procedure by tenotomy (Laraia et al. 2012, Barbosa et al. 2013) or tenectomy (Eliasson et al. 2012) and collagenase administration (Marsolais et al. 2001, Pires et al. 2011) are the most commonly used. Compression with guillotine (Salate et al. 2005, Joensen et al. 2012), crushing clamp (Carvalho et al. 2006), trauma load (Fillipin et al. 2005), electrical stimulation (CHO et al. 2011), mechanical overload with exercise (Glazebrook et al. 2008) and use of substances such as cytokines, anti- biotics and prostaglandins (Lui et al. 2011) are also mentioned. The tendinopathy induction protocol used in the present study had been previously tested (Silva et al. 2013) and proved to be efficient in promoting acute lesion in Wistar rats, which agrees with the scientific literature (Ress et al. 2006, Glazebrook et al. 2008).

Increased local temperature observed until $72 \mathrm{~h}$ after injury induction is a characteristic of the acute inflammatory process that results from increased vascular permeability and the release of various mediators involved in the inflammatory response. This characteristic has been reported in studies using rat tendon (Bilate 2007, Laraia et al. 2012).

The absence of pain sensitivity during physical assessment performed $12 \mathrm{~h}$ after surgery may be associated with the analgesic administered, which may have masked the pain symptoms. However, the rats remained free of pain during the following evaluations. In the groups receiving laser therapy, this absence can be explained by the analgesic effect of low-level laser (Hamblin \& Demidova 2006). This may increase the release of endorphins, which in turn amplify pain threshold (Moshkovska \& Mayberry 2005).

Despite the absence of sensitivity to pain, the possibility of discomfort from mechanical origin cannot be discarded, since the animals presented mild lameness during the evaluation of the locomotion capacity. Furthermore, the scale used for evaluation of sensitivity to pain might not have been adequate for the kind of induced injury. The scale adopted for physical examination followed the descriptions of Attal et al. (1990). It was used to assess abnormal pain-related sensation in rats due to common sciatic nerve injury; in other words, for more intense pain. Minville et al. (2008) used the same classification to check the response of rats with fracture in the tibia tuberosity treated with morphine or ketoprofen. According to the authors, the scale was effective in the identification of pain, and the drugs used promoted dose-dependent analgesia. However, because the fracture was caused by the blunt guillotine, it must have affected not only the bone tissue, but also the adjacent tissues. According to Oliva et al. (2004), periosteal injuries originating from orthopedic procedures cause more severe pain in the postoperative period than those performed in soft tissues.

The lowest $(p=0.0008)$ ability to move shown by the animals maintained at rest suggests the unfavorable effect of limited movement. According to Silva (2008), the scale allows for identifying minimum changes that are often imperceptible during deambulation assessment in the open field. The authors used the scale to evaluate the motor capacity of Wistar rats subjected to an experimental spinal cord injury by using $50.5 \mathrm{~g}$ stereotaxic equipment to apply pressure on the duramater for five minutes.

The gross findings in color and appearance of the tendon are compatible with those described by Nirschl \& Ashman (2003) for tendinopathy in humans. Deprivation of controlled eccentric exercise for one of the animals subjected only to laser therapy and one from the group at rest may have fostered the macroscopic appearance of the fibrinous tissue adhesions observed in the first postoperative week, which is related to fibroblast proliferation. According 
to Orhan et al. (2004), the appearance of adhesions depends on the degree of mobilization of the tendon during the healing period. With regard to the controlled physical activity, Nakamura et al. (2008) reported that physical exercise is essential for the recovery of the tendon, since it contributes to the realignment of tendon fibers. Additionally, it has been demonstrated that the immobilization of the limb may affect the biomechanical properties of the tendon (Wren et al. 2000). Moreover, Abate et al. (2009) reported that tissue adhesion is often observed between tendon and paratenon at the acute phase of tendinopathy. In fact, in addition to the inflammatory cells that move from the periphery of the tissue, adhesion formation is also related to other factors, such as extrinsic migration of fibroblasts (Sharma \& Maffulli 2005, James et al. 2008), excessive and uncontrolled growth of granulation tissue (Foland et al. 1992) and formation of scar tissue around the tendon sheath (Wang et al. 2012). These last two possibilities cannot be incriminated for causing injury in the rats in the present study, since exuberant granulation tissue was not formed in the tendons and there is not a true synovial sheath around the Achilles tendon, but instead, it has a paratenon. On the other hand, adhesion may have been caused by the stimulation of proliferation and extrinsic migration of fibroblasts from the peritenon. It contributes to the synthesis of the new tendon tissue and to the adhesion from the tendon to the adjacent tissues.

The histological evaluation revealed that laser therapy and/or exercises did not influence the characteristic hemorrhage, which suggests that the treatment did not result in important extravasation of blood. The results of this study differ from those of Eliasson et al. (2012), who observed this characteristic five days after surgical tendinopathy induction of the Achilles tendon of rats that performed treadmill running. The authors explain that the hemorrhage indicated tissue injury, but it was not sufficient to promote tendon damage. They attribute this finding to alternating periods of exercise (only $30 \mathrm{~min} /$ day) and rest, without further explanation about it.

Although the eccentric exercise protocol adopted did not cause important hemorrhage, morphometric analysis revealed that eccentric exercise results in a greater inflammatory reaction $(\mathrm{p}=0.0000)$, with group $\mathrm{x}$ time interaction on days 3 and 21, in comparison with the group that also received low-level laser. Although this inflammatory response was more pronounced only in the exercised animals, greater polymorphonuclear leukocyte infiltration was already expected in the early phase of the injury, followed by a subsequent reduction of the proliferative phase, which occurred in the third week after tendinopathy. This result was corroborated by histological analysis, which also showed greater $(p=0.0032)$ leukocyte infiltrate in the group treated solely with eccentric exercise. Therefore, despite the importance of physical activity in the recovery of tendinopathy, the present study shows that this therapy modality should be well measured (speed, duration, frequency and time of treatment), since the eccentric contraction may cause micro-ruptures of muscle fibers, as described by Clebis et al. (2001), which could attract inflammatory cells to the site of the injury.
Starting eccentric exercise only $24 \mathrm{~h}$ after injury induction may have been the cause of this mild increase in the local inflammatory process. Moreover, the decision to begin physical activity after one day of tendinopathy induction was aimed at standardizing the time of initiation of the treatment, as laser therapy should be initiated within the first hours after tendon injury because of its analgesic and anti-inflammatory effects. This time was considered ideal for starting the exercise, based on the protocol described by Nakamura et al. (2008), who observed a beneficial effect of downhill running initiated $24 \mathrm{~h}$ after surgical induction of tendinopathy of the patellar tendon of rats. However, unlike the findings of those authors, Godbout et al. (2006) reported that physical activity performed voluntarily (running wheel inside the cages, linked to an automatic counter) may have a negative effect, such as the extended inflammatory phase. The estimated distance traveled by the rats was approximately $118 \mathrm{~km}$ during the 28 days of evaluation, and the exercise was initiated immediately after collagenase-induced tendinopathy. On the other hand, because the physical activity was voluntary, the results cannot be compared with those obtained in the present study.

Still considering a mild, but feasible negative effect of eccentric exercise started only $24 \mathrm{~h}$ after lesion induction, the exercised rats showed greater $(p=0.0204)$ tendon thickening, which may be related to the intensity of the inflammatory process. Thickening of epitenon was observed by Orhan et al. (2004) in a study with the Achilles tendon of rats treated with extracorporeal shock waves therapy. As previously mentioned, over time, the group of animals that performed exercise alone presented higher rates $(p=0.0032)$ of infiltration of leukocytes in the inflammatory and proliferative phases, although the combination of exercise and laser therapy reduced these cells. In fact, the duration of the inflammatory phase of tendon repair process is contradictory and ranges from $24 \mathrm{~h}$ (Wang et al. 2006 ) to $72 \mathrm{~h}$ (Eliasson et al. 2009), or may even last for one week or longer than that (Dahlgren 2007). Inflammation is initially a beneficial event that aims to restore tissue and remove the aggressive agent. However, its prolongation might be detrimental to the injured tissue and even lead to the formation of fibrosis (Pohlers et al. 2009), considering that it is one of the sources of growth factors that act in tissue repair (McGrath 1990, Branton \& Kopp 1999). An example is the transforming growth factor beta, which is known for excessive stimulation of collagen production by fibroblasts (Klein et al. 2002), although it is essential to improve the mechanical strength of the tendon by reducing gene expression of type III procollagen and increasing type I procollagen expression.

Fibrinous tissue adhesion was quite common in the histological analysis, but there was no difference among groups or among times, though none of the rats subjected only to the eccentric exercise presented this characteristic in the final evaluation. This finding was characterized microscopically by the presence of fibrin, which is a protein involved in the coagulation cascade and formation of tissue matrix (Beretta 2005). 
Angiogenesis is critical to tissue oxygenation, as it benefits nutrition and remodeling of the tendon. In well-vascularized tendons, the tissue can recover quickly, but in those poorly vascularized, the repair process is slower, which increases the chances of reinjury (Pufe et al. 2005). The efficacy of laser therapy on the behavior of angiogenesis had already been mentioned by Lins et al. (2010), who reviewed the biostimulation effects of low-level laser on the tissue repair process. However, during this process, increased vascularity is initially expected, which should be followed by a subsequent reduction (Nakamura et al. 2008). This was exactly what occurred in animals that had been treated only with laser therapy. They presented the lowest $(p=0.0006)$ amounts of vessels when the groups were compared. On the other hand, the persistence of vascularization may lead to unsuitable and slower recovery of the tendon (Pufe et al. 2005).

Salate et al. (2005) also reported stimulation to angiogenesis resulting from treatment with low-level laser during the inflammatory and proliferative phases of the repair process of the Achilles tendon of rats. On the $4^{\text {th }}$ day of treatment, the authors observed a higher $(\mathrm{p}<0.05)$ number of vessels in the group treated with $10 \mathrm{~J} / \mathrm{cm}^{2}$. In the evaluation conducted after one week, the group undergoing laser therapy showed a higher $(\mathrm{p}<0.05)$ amount of vessels, compared with the control group.

Laser treatment provides some benefits including fibroblastic migration and proliferation (Hamblin \& Demidova 2006). It was more adequate (histological evaluation: $p=0.0024$, and morphometric evaluation: $p=0.0000$ ) in the group subjected to the therapy (Table 4, Fig.2d) compared with the group maintained at rest. Salate et al. (2005) report better alignment of the fibroblasts in the group subjected to laser treatment, which started six hours after tendinopathy induction by trauma, compared with the control group. These cells are critical for deposition and remodeling of extracellular matrix (Lui et al. 2007) and collagen synthesis. They emerge in the acute phase of injury and should be reduced significantly during the remodeling of the tendon, which may take months, thus exceeding the period of histological evaluation of the tendons in the present study.

Thermann et al. (2002) compared different treatments for tendinopathy of the Achilles tendon of rabbits and observed greater fibroblastic activity in the first and second weeks after lesion induction. This condition started to show reduction from the fourth week. Only after twelve weeks were the tendons histologically normal. This information suggests that the remodeling phase in these animals goes far beyond one month. Thus, a better histological analysis of the tendon repair process requires a longer period of assessment. The present study obtained results similar to those reported by these authors for the group of animals treated with laser therapy and eccentric exercise, for which a non-significantly reduced amount of fibroblasts was already observed three weeks after the beginning of the treatments. A decrease in these cells is desirable because an exaggerated fibroblastic activity may compromise the process of tendon repair (Pires et al. 2011). More specifically,
Lins et al. (2010) mention that the efficiency of low-level laser on tendon repair is due to induced mitotic activity of fibroblasts. In addition, the laser stimulates the production of basic fibroblast growth factor, which results in cell proliferation and differentiation.

Although no difference $(\mathrm{p}=0.2583)$ was found among groups and times evaluated for the organization of the collagen fibers, on the third day after the injury, a mild organization was already observed in animals from the groups subjected to eccentric exercise. Three weeks later, this characteristic presented moderate intensity in the group that performed physical activity. This result is probably due to the amount of type I collagen fibers observed in the third week with the use of the Picrosirius Red staining, in the groups treated with laser with or without eccentric exercise. Despite the likely adverse effects mentioned for the early introduction of physical activity after a tendon injury, the eccentric exercise walking on a treadmill was beneficial $(\mathrm{p}=0.0000)$ for the amount of collagen fibers, not only when used isolated, but also when combined with laser therapy. This activity was reported by Nakamura et al. (2008) as important to the remodeling response regarding the collagen fibers. Bring et al. (2007) reported better organization of collagen fibers in the group with rats subjected to eccentric exercise, compared with those immobilized with a padded plater and the control group, from the second to the fourth week after the onset of the experiment. According to Oliveira et al. (2009), this organization is essential to the tensile strength of the tendon.

With regard to laser therapy in the organization of collagen fibers, Salate et al. (2005) observed that the structure of the Achilles tendon of rats treated with laser therapy initiated $6 \mathrm{~h}$ after injury induction seemed more organized than that in the untreated group, already 5 days after the beginning of the therapy. Fillipin et al. (2005) reported better organization of these fibers in the same tendon in assessments conducted 14 and 21 days after trauma-induced injury. The results mentioned by those authors were very similar to that obtained in the present study and those reported by Arruda et al. (2007), who also used low-level laser at a dose of 3J with wavelengths of 670nm (aluminum gallium arsenide $=\mathrm{AlGaAs}$ ) and 904nm (GaAs).

In agreement with Salate et al. (2005), Oliveira et al. (2009) observed favorable effects after one week. However, unlike the other studies, the latter authors used the AlGaAs-based laser $\left(4 \mathrm{~J} / \mathrm{cm}^{2} ; 830 \mathrm{~nm}\right)$. In laser therapy, energy is produced by the use of an active medium that can be helium neon (He-Ne), GaAs, and also semiconductors of AlGaAs (Baxter 2003). Each of these active media operates with a specific wavelength. The active medium used (GaAs) in this study was suitable for the wavelength of $904 \mathrm{~nm}$, which is appropriate for the type of induced injury.

Increased amount of type I collagen was reported two weeks after tendon injury in rats, either using laser therapy associated with platelet-rich plasma (PRP) (Barbosa et al. 2013) or only the platelet-rich component (Kajikawa et al. 2008) by histology and immunohistochemical expression, respectively. Barbosa et al. (2013) reported a higher value $(\mathrm{p}<0.05)$ of type I fibers in the Achilles tendon of rats with 
partial tenotomy 13 days after the start of laser therapy (7J; $\lambda 660 \mathrm{~nm}$ or $\lambda 830 \mathrm{~nm}$ ) associated with PRP. However, no difference ( $p>0.05)$ was found between the groups treated only with laser therapy, with the use of different $(\lambda 660 \mathrm{~nm}$ and $\lambda 830 \mathrm{~nm}$ ) wavelengths. On the other hand, the rats treated only with laser presented a larger $(\mathrm{p}<0.05)$ amount of type I and III fibers than those treated with PRP simply. In addition, type III collagen fibers were more numerous ( $p>0.05)$ in the treated groups. The results achieved by those authors suggest that PRP alone did not provide a result as satisfying as that obtained when laser therapy was combined with it. These better results found by these researchers may be related to the amount of points of application, which were, in their case, three 20 -second periods. The present study used one point with the duration of 9s.

The exaggerated increase in type III collagen fibers in the group undergoing laser therapy was not significant, perhaps due to the high standard deviation, which was $32.34 \pm 16.96$. On the other hand, the early rise of type III collagen was already expected, since soon after a tendon injury, this collagen must prevail (Kajikawa et al. 2008), because of its role in the maintenance of the structure of the tendon (Barbosa et al. 2013). Although early increased type III collagen is desirable shortly after a tendon injury, its reduction must occur gradually, since it is less resistant (Barbato 2011) than type I collagen. That was exactly what happened, since a reduction was observed $(p=0.0305)$ in the amount of this collagen in the group receiving laser therapy associated with eccentric exercise, in the evaluation performed 21 days after tendinopathy induction.

Studies have shown that the treadmill exercise was beneficial to the recovery of the tendon (See et al. 2004, Barbato 2011), when it started five days or one week after injury induction in the Achilles tendon of rats. The results obtained in the present research support the hypothesis that the combination of laser therapy and eccentric exercise may provide better results for tendon repair than the treatments performed isolated (only eccentric exercise or laser therapy). Therefore, controlled studies are necessary for the assessment of different times for the introduction of eccentric exercise or laser therapy.

\section{CONCLUSIONS}

Laser therapy, at a dose of 3J and a wavelength of $904 \mathrm{~nm}$, associated with eccentric exercise, started $24 \mathrm{~h}$ after induced tendinopathy of the Achilles tendon of Wistar rats, increases the amount of collagen fibers, with a subsequent reduction of type III fibers, despite extending angiogenesis.

This treatment also reduces the possibility of fibrinous adhesion formation and improves the organization of collagen fibers.

Therefore, when eccentric exercise is performed concomitantly with low-level laser, it improves the histological characteristics of the injured tendon.

Acknowledgments.- The authors are thankful to Coordenação de Aperfeiçoamento de Pessoal de Nível Superior (CAPES) for grating scholarships, as well as Fundação de Amparo à Pesquisa do estado de Minas Gerais (Fapemig) and Conselho Nacional de Desenvolvimento Científico e
Tecnológico (CNPq) for the support and assistance in the research activities (Document no. CNPq: 472832/2012-3).

\section{REFERENCES}

Abate M., Gravare-Silbernagel K., Siljeholm C., Di Lori A., De Amicis D., Salini V., Werner S. \& Paganelli R. 2009. Pathogenesis of tendinopathies: inflammation or degeneration? A review. Arthritis Res. Ther. 11:1-15.

Alfredson H. 2003. Chronic midportion Achilles tendinopathy: an update on research and treatment. Clin. Sports Med. 22:727-741.

Alfredson H., Ljung B.-O., Thorsen K. \& Lorentzon R. 2000. In vivo investigation of ECRB tendons with microdialysis technique-no signs of inflammation but high amounts of glutamate in tennis elbow. Acta Orthop. Scand. 71:475-479.

Andres B.M. \& Murrell G.A.C. 2008. Treatment of tendinopathy: what works, what does not and what is on horizon. Clin. Orthop Relat. Res. 466:1539-1554.

Arruda E.R.B., Rodrigues N.C., Taciro C. \& Parizotto N.A. 2007. Influência de diferentes comprimentos de onda da laserterapia de baixa intensidade na regeneração tendínea de rato após tenotomia. Revta Bras. Fisioter. 11:283-288.

Attal N., Jazat F., Kayser V. \& Guilbaud G. 1990. Further evidence for "pain-related" behaviours in a model of unilateral peripheral mononeuropathy. Pain 41:235-251.

Barbato K.B.G. 2011. Efeito do uso de antiinflamatório e do exercício aeróbico sobre a regeneração tecidual e perfil biomecânico do tendão calcâneo de ratos após ruptura completa. Tese de Doutorado em Fisiopatologia Clínica e Experimental, Universidade do Estado do Rio de Janeiro, Rio de Janeiro, RJ. 76p.

Barbosa D., Souza R.A., Carvalho W.R.G., Xavier M., Carvalho P.K., Cunha C.R., Arisawa E.A.L., Silveira J.R.L. \& Villaverde A.B. 2013. Low-level laser therapy combined with platelet-rich plasma on the healing calcaneal tendon: a histological study in a rat model. Lasers Med. Sci. 28:1489-1494.

Baxter D. 2003. Laserterapia de baixa intensidade, p.342-382. In: Kitchen S. (Ed.), Eletroterapia Prática Baseada em Evidência. EDN 11. Manole, São Paulo.

Beretta D.C. 2005. Influência da estimulação elétrica transcutânea na cicatrização do tendão do ventre lateral do músculo gastrocnêmio em coelhos. Dissertação de Mestrado em Ciências Veterinárias (Clínica e Cirurgia), Universidade Federal de Uberlândia, Uberlândia, MG. 47p.

Bilate A.M.B. 2007. Inflamação, proteínas de fase aguda, citocinas e quimiocinas. Temas Reumat. Clin. 8:86-90.

Bjordal J.M., Lopes-Martins R.A.B., Joensen J., Couppe C., Ljunggren A.E., Stergioulas A. \& Johnson M.I. 2008. A systematic review with procedural assessments and meta-analysis of low level laser therapy in lateral elbow tendinopathy (tennis elbow). BMC Musculoskelet. Disord. 29:1-15.

Branton M.H. \& Kopp J.B. 1999. TGF-beta and fibrosis. Microbes Infect. 1:1349-1365.

Bring D.K.-I., Kreicbergs A., Renstrom P.A.F.H. \& Ackermann P.W. 2007. Physical activity modulates nerve plasticity and stimulates repair after Achilles tendon rupture. J. Orthop. Res. 25:164-172.

Carvalho P.T.C., Silva I.S., Reis F.A., Belchior A.C.G., Aydos R.D., Facco G.G. \& Dourado D.M. 2006. Histological study in malnourished Wistar rats treated with ultrasound therapy. Acta Cir. Bras. 21:13-17.

Clebis N.K. \& Natali M.J.M. 2001. Lesões musculares provocadas por exercícios excêntricos. Revta Bras. Ciênc. Mov. 9:47-53.

Cho N.S., Hwang J.H., Lee Y.T. \& Chae S.W. 2011. Tendinosis-like histologic and molecular changes of the Achilles tendon to repetitive stress. Clin. Orthop. Relat. Res. 469:3172-3180.

Dahlgren L.A. 2007. Pathobiology of tendon and ligament injuries. Clin. Tech. Equine Pract. 6:168-173.

Dogan S.K., Ay S. \& Evick D. 2010. The effectiveness of low laser therapy in subacromial impingement syndrome: a randomized placebo controlled double-blind prospective study. Clinics 65:1019-1022.

Eliasson P., Andersson T. \& Aspenberg P. 2009. Rat Achilles tendon healing: mechanical loading and gene expression. J. Appl. Physiol. 107:399-407.

Eliasson P., Andersson T. \& Aspenberg P. 2012. Achilles tendon healing in rats is improved by intermittent mechanical loading during the inflammatory phase. J. Orthop. Res. 30:274-279. 
Fillipin L., Mauriz J.L., Vedoveli K., Moreira A.J., Zettler Z.G., Lech O., Maronni N.P. \& González-Gallego J. 2005. Low-level laser therapy (LLLT) prevents oxidative stress and reduces fibrosis in rat traumatized Achilles tendon. Lasers Surg. Med. 37:293-300.

Foland J.W., Trotter G.W., Powers B.E., Wringley R.H. \& Smith F.W. 1992. Effect of sodium hyaluronate in collagenase-induced superficial digital flexor tendinitis in horses. Am. J. Vet. Res. 53:2371-2376.

Frick A. 2010. Stretching exercise for horses: are they effective? J. Equine Vet Sci. 30:50-59.

Glazebrook M.A., Wright J.R., Langman M., Stanish W.D. \& Lee M. 2008. Histological analysis of Achilles tendons in an overuse rat model. J. Orthop. Res. 26:840-846.

Godbout C., Ang 0. \& Frenette J. 2006. Early voluntary exercise does not promote healing in a rat model of Achilles tendon injury. J. Appl. Physiol. 101:1720-1726.

Hamblin M.R. \& Demidova T.N. 2006. Mechanisms of low level light therapy. Proc. SPIE 6140:1-12.

Isner-Horobeti M.E., Dufour S.P., Vautravers P., Geny B., Coudeyre E. \& Richard R. 2013. Eccentric exercise training: modalities, applications and perspectives. Sports Med. 43:483-512.

James R., Kesturu G., Balian G. \& Chhabra A.B. 2008. Tendon: biology, biomechanics, repair, growth, factors and envolving treatment options: a review. J. Hand. Surg. Am. 33:102-112.

Joensen J., Gjerdet N.R., Hummelsund S., Iversen V., Lopes-Martins R.A.B. \& Bjordal J.M. 2012. An experimental study of low-level laser therapy in rat Achilles tendon injury. Lasers Med. Sci. 27:103-111.

Kajikawa Y., Morihara T., Sakamoto H., Matsuda K., Oshima Y., Yoshida A., Nagae M., Arai Y., Kawata M. \& Toshikazu K. 2008. Platelet-rich plasma enhances the initial mobilization of circulation-derived cells for tendon healing. J. Cell. Physiol. 215:837-845.

Khan K.M., Cook J.L., Bonar F., Harcourt P. \& Astrom M. 1999. Histopathology of common tendinopathies. Update and implications for clinical management. Sports Med. 27:393-408.

Klein M.B., Yalamanchi N., Pham H., Longaker M.T. \& Chang J. 2002. Flexor tendon healing in vitro: effect of TGF- $\beta$ on tendon cell collagen production. J. Hand Surg. 27A:615-620.

Laraia S.E.M., Silva I.S., Pereira D.M., Reis F.A., Almeida P., Leal Júnior E.C.P. \& Carvalho P.T.C. 2012. Effect of low-level laser therapy $(660 \mathrm{~nm})$ on acute inflammation induced by tenotomy of Achilles tendon in rats. Photoch. Photobiol. 88:1546-1550.

Lins R.D.A.U., Dantas E.M., Lucena K.C.R., Catão M.H.C.V., Granville-Garcia A.F. \& Carvalho Neto L.G. 2010. Efeitos bioestimulantes do laser de baixa potência no processo de reparo. Anais Bras. Dermatol. 85:849-855.

Lui P.P., Cheuk Y.C., Hung L.K., Fu S.C. \& Chan K.M. 2007. Increased apoptosis at the late stage of tendon healing. Wound Rep. Reg. 17:702-707.

Lui P.P., Maffulli N. \& Smith R.K.W. 2011. What are the validated animal models for tendinopathy? Review. Scand J. Med. Sci. Sports 21:3-17.

Maffulli N., Wong J. \& Almekinders L.C. 2003. Types and epidemiology of tendinopathy. Clin. Sports Med. 22:675-692.

Marsolais D., Côté C.H. \& Frenette J. 2001. Neutrophils and macrophages accumulate sequentially following Achilles tendon injury. J. Orthop. Res. 19:1203-1209.

McGrath M.H. 1990. Peptide growth factors and wound healing. Clin. Plast. Surg. 17:421-432

Minville V., Laffosse J.-M., Fourcade 0. \& Girolami J.-P. 2008. Mouse modelo fracture pain. Anesth. 108:467-472.

Moshkovska T. \& Mayberry J. 2005. It is time to test low level laser therapy in Great Britain. Postgrad. Med. J. 81:436-441.

Movin T., Gad A., Reinholt F.P. \& Rolf C. 1997. Tendon pathology in longstanding achillodynia biopsy findings in 40 patients. Acta Orthop. Scand. 68:170-175

Nakamura K., Kitaoka K. \& Tomita K. 2008. Effect of eccentric exercise on healing process of injured patellar tendon in rats. J. Orthop. Sci. 13:371-378.

Nirschl R.P. \& Ashman E.S. 2003. Elbow tendinopathy: tennis elbow. Clin. Sports Med. 22:813-836.

Oliva V.N.L.S., Maia L.A.A., Silva B.M., Saito L.M. \& Perri S.H.V. 2004. Avaliação clínica de diferentes antiinflamatórios não esteróides na analgesia pós-operatória de cirurgias ortopédicas em cães. Clin. Vet. 50:42-54.
Oliveira F.S., Pinfildi C.E., Parizoto N.A., Liebano R.E., Bossini P.S., Garcia I.B. \& Ferreira L.M. 2009. Effect of low level laser therapy $(830 \mathrm{~nm})$ with different therapy regimes on the process of tissue repair in partial lesion calcaneous tendon. Lasers Surg. Med. 41:271-276.

Orhan Z., Ozturan K., Given A. \& Cam K. 2004. The effect of extracorporeal shock waves on a rat model of injury to tendo Achillis: a histological and biomechanical study. J. Bone Joint Surg., Brit. 86-B:613-618.

Pires D., Xavier M., Araújo T., Silva Júnior J.A., Aimbre F. \& Albertini R. 2011. Low-level laser therapy (LLLT; $780 \mathrm{~nm}$ ) acts differently on mRNA expression of anti- and pro-inflammatory mediators in an experimental model of collagenase-induced tendinitis in rat. Lasers Med. Sci. 26:8594.

Pohlers D., Brenmoehl J., Löffer I., Müller C.K., Leipner C., Schultze-Mosgau S., Stallmach A., Kinne R.W. \& Wolf G. 2009. TGF- $\beta$ and fibrosis in different organs molecular pathway imprints. Biochim. Biophys. Acta 1792:746-756.

Pufe T., Petersen W.J., Mentlein R. \& Tillmann B.N. 2005. The role of vasculature and angiogenesis of degenerative tendons disease. Scand. J. Med. Sci. Sports 15:211-22.

Ress J.D., Wilson A.M. \& Wolman R.L. 2006. Current concepts in the management of the discorders. Rheumatol. 45:508-521.

Salate A.C.B., Barbosa G., Gaspar P., Koeke P.U., Parizotto N.A., Benze B.G. \& Foschiani D. 2005. Effect of In-Ga-Al-P Diode laser irradiation on angiogenesis in partial ruptures of Achilles tendon in rats. Photomed. Laser Surg. 23:470-575.

See E.K.N., Ng G.Y.F., Ng C.O.Y. \& Fung D.T.C. 2004. Running exercise improve the strength of a partially ruptured Achilles tendon. Brit. J. Sports Med. 38:597-600.

Sharma P. \& Maffulli N. 2005. Tendon injury and tendinopathy: healing and repair. J. Bone Joint Surg. Am. 87:187-202.

Silva C.M.O. 2008. Efeito da prednisona em lesão medular aguda experimental em ratos (Rattus novergicus). Dissertação de Mestrado em Medicina Veterinária, Área de Medicina e Cirurgia, Universidade Federal de Minas Gerais, Belo Horizonte, MG. 46p.

Silva J.M.N., Carvalho J.P. \& Moura Júnior M.J. 2011. Estudo morfométrico da terapia LED de baixa potência em tendinite de ratos. Fisioter. Pesq. 18:365-370

Silva M.O., Costa M.B.M., Borges A.P.B., Dornas R.F., Moreira J.C.L. \& Souza M.V. 2013. Indução de tendinopatia em ratos Wistar: modelo experimental. Revta Acad. Ciênc. Agrár. Ambient. 11:275-282.

Soslowsky L.J., Thomopoulos S., Tun S., Flanagan C.L., Keefer C.C., Mastaw J., Carpenter J.E. \& Mich A.A. 2000. Overuse activity injures the supraspinatus tendon in an animal model: A histologic and biomechanical study. J. Shoulder Elbow Surg. 9:79-84.

Taciro C., Serikawa M.A. \& Parizzoto N.A. 2007. Aspectos nanoestruturais do colágeno no processo de regeneração tendínea estimulada por laser de baixa intensidade: estudo piloto. Fisioter. Espec. 1:20-24.

Thermann H., Frerichs 0., Holch M. \& Biewener A. 2002. Healing of Achilles tendon, an experimental study. 2. Histological, immunochistological and ultrasonographic. Foot Ankle Intern. 23:606-613.

Wang J.H.-C., Iosifidis M.I. \& Fu F.H. 2006. Biomechanical basis for tendinopathy: a review. Clin. Orthop. Relat. Res. 443:320-332.

Wang J.H.-C., Guo Q. \& Li B. 2012. Tendon biomechanics and mechanobiology - a minireview of basic concepts and recent advancements. J. Hand Ther. 25:133-140.

Warden S.J. 2007. Animal models for the study of tendinopathy: a review. Brit. J. Sports Med. 41:232-240.

Wren A.L., Beaupré G.S. \& Carter D.R. 2000. Tendon and ligament adaptation to exercise, immobilization, and remobilization. J. Rehabil. Res. Dev. 3:217-224.

Xavier M., David D.R., de Souza R.A., Arrieiro A.N., Miranda H., Santana E.T., Silva Jr J.A., Salgado M.A. \& Albertini R. 2010. Anti-inflammatory effects of low-level light emitting diode therapy on Achilles tendinitis in rats. Lasers Surg. Med. 42:553-558.

Zandim B.M., Souza M.V., Frassy L.M., Vilória M.I.V., Maia L., Fonseca C.C., Valente F.V., Moreira J.C.L. \& Magalhães P.C. 2013. Immunohistochemistry of factor VIII, histology and morphometry in equine tendon treated with platelet-rich plasma. Vet. Bras. Med. Vet. 35:169-184. 